\title{
PENGARUH PENGGUNAAN THINK PAIR SHARE (TPS) MELALUI KEAKTIFAN BELAJAR TERHADAP KEMAMPUAN KOMUNIKASI MATEMATIS SISWA KELAS VII SMP
}

\section{THE INFLUENCE OF THE USE OF THINK PAIR SHARE (TPS) THROUGH LEARNING ACTIVITIES ON THE MATHEMATICAL COMMUNICATION ABILITY OF CLASS VII STUDENTS IN SMP}

\author{
Putra Wahidin M.1), M. Yusuf T 2), Andi Dian Angriani ${ }^{3)}$ \\ 1, 2, 3 Fakultas Tarbiyah dan Keguruan UIN Alauddin Makassar \\ pwahidin@gmail.com ${ }^{1}$,yustar2ef@gmail.com ${ }^{2}$, dian.angriani@uin-alauddin.ac.id ${ }^{3}$.
}

\begin{abstract}
Abstrak
Penelitian ini bertujuan untuk mengetahui tentang pengaruh model Think Pair Share pada mata pelajaran sistem persamaan liniear satu variabel pada kelas VII SMPN 2 Balocci. Jenis penelitian yang digunakan adalah quasi experiment dengan desain factorial desain dan rancangan penelitian treatment by level $2 \times 2$. Populasi pada penelitian ini adalah seluruh peserta didik kelas VII SMPN 2 Balocci yang berjumlah 120 orang. Sampel pada penelitian ini adalah kelas VII1 sebagai kelas eksperimen dan kelas VII2 sebagai kelas kontrol. Instrumen penelitian yang digunakan dalam penelitian ini adalah tes kemampuan pemahaman konsep dan tes kemampuan representasi matematis. Berdasarkan hasil penelitian yang dilakukan terhadap kelas eksprimen dan kelas kontrol, diperoleh bahwa (1) Pembelajaran menggunakan model TPS untuk kelas eksperimen nilai post test jauh lebih baik dari pada nilai pre test yaitu nilai maksimum post test adalah 88 sedangkan pada kelas kontrol nilai maksimum post test 85;(2) kemampuan komunikasi matematis pada hasil post test kelas eksperimen kategorinya lebih baik dibanding kelas kontrol;(3) keaktifan belajar pada kelas eksperimen kategorinya lebih baik dari pada kelas kontrol, Kesimpulan hasil penelitian adalah terdapat perbedaan yang signifikan antara TPS dan metode konvensional terhadap kemampuan komunikasi matematis siswa kelas VII SMPN 2 Balocci, yaitu pembelajaran dengan model TPS lebih efektif meningkatkan kemampuan komunikasi matematis siswa daripada metode konvensional dan juga terdapat pengaruh interaksi antara model pembelajaran ditinjau dari keaktifan belajar terhadap kemampuan komunikasi matematis siswa kelas VII SMPN 2 Balocci.
\end{abstract}

Kata Kunci: komunikasi matematika, TPS, keaktifan belajar

\begin{abstract}
This study aims to find out about the influence of the Think Pair Share model on subjects of a linear variable system of variables in class VII of SMPN 2 Balocci. This type of research is a quasi experiment with factorial design and treatment design by $2 \times 2$ level. The population in this study were all students of class VII at SMPN 2 Balocci, totaling 120 people. The sample in this study was class VII1 as an experimental class and class VII2 as a control class. The research instrument used in this study was a test of concept comprehension ability and a mathematical representation ability test. Based on the results of research conducted on the experimental class and the control class, it was found that (1) Learning using the TPS model for the experimental class the post test value was far better than the pre test value ie the maximum post test value was 88 while in the control class the maximum post test value 85; (2) mathematical communication skills in the experimental class post test results the category is better than the control class, (3) learning activity in the experimental class the category is better than the control class. The conclusion of the results of the study is that
\end{abstract}


there is a significant difference between TPS and conventional methods on the mathematical communication skills of Grade VII students of SMPN 2 Balocci, that learning with the TPS model is more effective in increasing students' mathematical communication abilities than conventional methods. There is also an influence of interaction between learning models in terms of learning activeness towards mathematical communication skills of Grade VII students of SMPN 2 Balocci.

Keywords: mathematical communication, think pair share, learning activity

How to Cite: Wahidin, P., Yusuf, M., \& Angriani, A.D. (2019). Pengaruh penggunaan Think Pair Share (TPS) melalui keaktifan belajar terhadap kemampuan komunikasi matematis siswa kelas VII SMP. Al-Asma: Journal of Islamic Education, 1(2), 115-124.

\section{PENDAHULUAN}

Pendidikan adalah hak semua orang tanpa terkecuali. Tiap manusia berhak atas pendidikan yang layak. Pendidikan dipilih sebagai alternatif utama pengembangan budaya dan karakter karena pendidikan merupakan sarana dalam membangun generasi baru. Melalui pendidikan diharapkan dapat terwujudnya peningkatan kualitas generasi muda yang mampu meminimalisasi penyebab berbagai permasalahan budaya dan karakter (Nanik, 2010: 8). Pendidikan di Indonesia terdapat beberapa mata pelajaran dasar. Salah satu pelajaran dasar yang sangat penting dikuasai oleh siswa mulai dari tingkat dasar sampai tingkat atas adalah matematika. Pada umumnya pelajar mulai dari jenjang pendidikan dasar sampai di perguruan tinggi menganggap bahwa matematika merupakan salah satu mata pelajaran yang sangat sulit.

Pembelajaran matematika merupakan salah satu hal yang diduga dapat mewujudkan tujuan pendidikan, matematika merupakan suatu ilmu utama dalam meningkatkan intelektual, selain pengetahuan mengenai matematika itu sendiri, matematika juga dapat memberikan ilmu suatu bentuk dan kekuasaan dalam bahasa, proses dan teori. Dalam pengembangan berbagai ilmu pengetahuan kegunaan matematika menjadi sangat penting. Dasar desain ilmu teknik merupakan salah satu contoh pemanfaatan perhitungan matematis, selain itu cara matematis dapat dijadikan inspirasi kepada pemikiran matematis serta dapat membeikan ide dalam kegiatan arsitektur dan seni lukis (Surajiyo, 2009: 41).

Sanjaya mengungkapkan bahwa coopertive learning merupakan kegiatan belajar siswa yang dilakukan dengan cara berkelompok. Model pembelajaran kelompok adalah rangkaian kegiatan belajar yang dilakukan oleh siswa dalam kelompok-kelompok tertentu untuk mencapai tujuan pembelajaran yang telah dirumuskan. Sedangkan menurut Tom V.Savage, cooperative learning adalah suatu pendekatan yang menekankan kerja sama dalam kelompok (Rusman, 2016: 203). Menurut (Agus, 2014: 65), sintak model pembelajaran kooperatif terdiri dari enam fase, yaitu: 1) menyampaikan tujuan dan mempersiapkan peserta didik, 2) menyajikan informasi, 3) mengorganisir peserta didik ke dalam tim-tim belajar, 4) membantu kerja tim dan belajar. 5) mengevaluasi, 6) memberikan pengakuan atau penghargaan.

Think Pair Share (TPS) merupakan salah satu tipe dari model pembelajaran kooperatif. Think Pair Share (TPS) merupakan metode pembelajaran yang dikembangkan pertama kali oleh Profesor Frank Lyman di University of Maryland pada tahun 1981 dan 
diadopsi oleh banyak penulis di bidang pembelajaran kooperatif pada tahun-tahun selanjutnya. Metode ini memperkenalkan gagasan tentang waktu 'tunggu atau berpikir' (wait or think tim) pada elemen interaksi pembelajaran kooperatif yang saat ini menjadi salah satu faktor ampuh dalam meningkatkan respons siswa terhadap pertanyaan (Huda,2015: 206).

Pada dasarnya, model pembelajaran kooperatif tipe TPS merupakan suatu cara yag efektif untuk membuat variasi suasana pola diskusi kelas. Dengan asumsi bahwa semua resitasi atau diskusi membutuhkan pengaturan untk mengendalikan kelas secara keseluruhan, dan prosedur yang digunakan dalam TPS dapat memberi siswa lebih banyak waktu berpikir, untuk merespon dan saling membantu. Model pembelajaran kooperatif tipe Think Pair Share menggunakan metode diskusi berpasangan yang dilanjutkan dengan diskusi pleno (Kurniasih, 2016: 58).

Think Pair Share mendorong interaksi antar siswa. Selain itu, metode ini mampu menciptakan lingkungan belajar yang menyenangkan dan dapat meningkatkan keaktifan belajar. Siswa menjadi lebih kooperatif dan mampu berkomunikasi dengan baik(Huda,2015:206). Menurut (Abdullah, 2014: 195) Sintaks Model Pembelajaran Kooperatif tipe Think-Pair-Share sebagai berikut:

Tabel. 1 Sintaks Model Pembelajaran Kooperatif Tipe Think-Pair-Share

\begin{tabular}{|c|c|}
\hline Langkah-langkah & Kegiatan pembelajaran \\
\hline $\begin{array}{l}\text { Fase-1 } \\
\text { pendahuluan }\end{array}$ & $\begin{array}{l}\text { - Guru menjelaskan aturan main dan batasan waktu } \\
\text { untuk tiap kegiatan, memotivasi siswa terlibat pada } \\
\text { aktivitas pembelajaran } \\
\text { - Guru menjelaskan kompetensi yang harus dicapai oleh } \\
\text { siswa }\end{array}$ \\
\hline $\begin{array}{l}\text { Fase-2 } \\
\text { Think }\end{array}$ & $\begin{array}{l}\text { - Guru menggali pengetahuan awal siswa melalui } \\
\text { kegiatan demonstrasi } \\
\text { - Guru memberikan lembar kerja siswa (LKS) kepada } \\
\text { seluruh siswa } \\
\text { - Siswa mengerjakan LKS tersebut secara individu }\end{array}$ \\
\hline $\begin{array}{l}\text { Fase-3 } \\
\text { Pair }\end{array}$ & $\begin{array}{l}\text { - Siswa dikelompokkan dengan teman sebangkunya } \\
\text { - Siswa berdiskusi dengan pasangannya mengenai } \\
\text { jawaban tugas yang telah dikerjakan }\end{array}$ \\
\hline $\begin{array}{l}\text { Fase-4 } \\
\text { Share }\end{array}$ & $\begin{array}{l}\text { - Satu pasang siswa dipanggil secara acakuntuk berbagi } \\
\text { pendapat kepada seluruh siswa di kelas dengan } \\
\text { dipandu oleh guru }\end{array}$ \\
\hline $\begin{array}{l}\text { Fase-5 } \\
\text { Penghargaan }\end{array}$ & - Siswa dinilai secara individu dan kelompok \\
\hline
\end{tabular}

Menurut (NCTM,2000:29) terdapat lima kemampuan matematis yang harus dimiliki siswa yaitu (1) belajar untuk berkomunikasi (mathematical communication); (2) belajar untuk bernalar (mathematical reasoning); (3) belajar untuk memecahkan masalah (mathematical problem solving); (4) belajar untuk mengaitkan ide (mathematical connection); (5) belajar untuk merepresentasikan ide-ide (mathematical representation). 
Kemampuan komunikasi matematis adalah kemampuan menyampaikan gagasan/ide matematis, baik secara lisan maupun tulisan serta kemampuan memahami dan menerima gagasan/ide matematis orang lain secara cermat, analitis, kritis dan evaluative untuk mempertajam pemahaman (Karunia Eka, 2006: 83).

Menurut National Concil of Teachers of Mathematics (NCTM, 2000: 61) komunikasi matematis adalah kecakapan peserta didik dalam mengungkapkan ide-ide matematika secara lisan, tertulis, gambar, diagram, menggunakan benda nyata atau menggunakan simbol matematika. Secara umum matematika berfokus pada refresentasi dan komunikasi dalam berbagai gagasan, ide, dan hubungan yang bersifat numeric, spasial, serta berkenaan dengan data. Ada banyak aktivitas pembelajaran yang mendukung tema ini, seperti siswa yang boleh menginterpretasikan ide, gagasan, ataupun pikiran-pikiran yang konseptual yang mereka miliki sendiri kedalam bentuk simbolik dan dapat diubah kedalam gambaran verbal dari situasi tersebut. Dilihat dari disiplin matematika, teori informasi menggunakan ilmu matematika untuk mengukur efek komunikasi (Inge,2015:11).

Menurut (Azizah, 2011: 24) yang dikutip dari Satriawati kemampuan komunikasi matematis siswa dapat dilihat melalui indikator: 1)Penjelasan Matematika: menjelaskan suatu masalah dengan memberikan argumentasi terhadap permasalahan matematika, 2)Menggambarkan Matematika: dapat melukiskan gambar matematika, 3)Ekspresi Matematika: menyatakan ide matematika menggunakan simbol atau bahasa matematika secara tertulis.

Belajar merupakan sebuah manifestasi diri untuk dapat mengenal sesuatu yang sedang dibaca atau dipelajari secara lebih mendalam dan serius sehingga ada sesuatu yang subtansial yang bisa diperoleh. Dalam kegiatan belajar, ada sebuah proses berpikir kritis yang sedang dilakukan secara serius dan tegas(Yamin,2015:6). Keaktifan belajar haruslah mengarah kekadar keterlibatan subyek didik setinggi mungkin. Subyek didik harus diberi kesempatan seluas mungkin untuk dapat menyerap struktur informasi masuk dalam struktur kognisinya atau menyesuaikan pada sruktur baru sehingga tercapai kebermaknaan optimal, menghayati sebuah peristiwa yang dipelajari agar terjadi proses afektif dan internalisasi nilai, dan melakukan langsung aktivitas operasionalnya, sehingga memiliki konseptualisasi teoritik dan operasionalisasinya atau fungsionalisasinya (Yamin,2015:6).

Keaktifan belajar haruslah mengarah kekadar keterlibatan subyek didik setinggi mungkin. Subyek didik harus diberi kesempatan seluas mungkin untuk dapat menyerap struktur informasi masuk dalam struktur kognisinya atau menyesuaikan pada sruktur baru sehingga tercapai kebermaknaan optimal, menghayati sebuah peristiwa yang dipelajari agar terjadi proses afektif dan internalisasi nilai, dan melakukan langsung aktivitas operasionalnya, sehingga memiliki konseptualisasi teoritik dan operasionalisasinya atau fungsionalisasinya (Yamin, 2015: 7).

Menurut (Suhana, 2014: 8) Keberhasilan dalam belajar sangat dipengaruhi oleh berfungsinya secara integratif dari setiap faktor pendukungnya. Adapun faktor-faktor yang mempengaruhi keberhasilan belajar antara lain: 1) Peserta didik dengan sejumlah latar belakangnya, yang mencakup: tingkat kecerdasan (intelligent quotient), bakat (aptitude), sikap (attitude), minat (interest), motivasi (motivation), keyakinan (belief), kesadaran (consciousness), kedisiplinan (discipline); 2) Pengajar professional yang 
memiliki kompetensi pedagogic, kompetensi kepribadian, kompetensi sosial, kompetensi profesional; 3) Atmosfir pembelajaran partisipatif dan interaktif yang dimanifestasikan dengan adanya komunikasi timbal balik secara aktif, kreatif, efektif, inovatif, dan menyenangkan; 4) Kurikulum sebagai kerangka dasar atau arahan khusus mengenai perubahan perilaku (behavior chage) peserta didik secara integral, baik yang berkaitan dengan kognitif, afektif, maupun psikomotor; 5) Lingkungan agama, sosial, budaya, politik, ekonomi, ilmu dan teknologi, serta lingkungan alam sekitar, yang mendukung terlaksananya proses pembelajaran secara aktif, kreatif, efektif, inovatif, dan menyenangkan. Lingkungan ini merupakan faktor peluang untuk terjadinya belajar kontekstual; 6) Atmosfir kepemimpinan pembelajaran yang sehat, partisipatif, demokratis, dan situasional yang dapat membangun kebahagiaan intelektual, kebahagiaan emosional, kebahagiaan dalam merekayasa ancaman menjadi peluang dan kebahagiaan spiritual; 7) Pembiayaan yang memadai, baik biaya rutin, mapun biaya pembangunan yang datangnya dari pihak pemerintah, orang tua maupun lainnya, sehingga sekolah mampu melangkah maju dari sebagai pengguna dana menjadi penggali dana; 8) Peningkatan Mutu Pembelajaran, pembelajaran yang baik adalah pembelajaran yang menuntut keaktifan siswa. Dalam pembelajaran yang demikian, siswa tidak lagi ditempatkan dalam posisi pasif sebagai penerima bahan ajaran yang diberikan guru, tetapi sebagai subjek yang aktif melakukan proses berpikir, mencari, mengolah, mengurai.

\section{METODE PENELITIAN}

Pendekatan yang digunakan pada penelitian ini adalah pendekatan kuantitatif dengan jenis penelitian yang digunakan adalah eksperimen semu (quasi eksperiment). Desain penelitian yang digunakan oleh penelitian yang digunakan oleh peneliti adalah Factorial Design. Desain ini merupakan desain yang memperhatikan adanya variabel lain dalam hubungan antara variabel bebas dan variabel tak bebas, yang biasa disebut sebagai variabel moderator.

Berdasarkan desain penelitian, Rancangan penelitian yang digunakan adalah rancangan treatment by level $2 \times 2$, sedangkan digambarkan dalam tabel berikut ini:

Tabel 2. Rancangan Penelitian

Rancangan treatment by level $2 \times 2$

\begin{tabular}{llll}
\hline & & \multicolumn{2}{c}{$\mathbf{A}$} \\
\cline { 2 - 4 } & & TPS $\left(\mathbf{A}_{\mathbf{1}}\right)$ & Tanpa TPS $\left(\mathbf{A}_{\mathbf{2}}\right)$ \\
\hline Keaktifan & Tinggi $\left(\mathrm{B}_{1}\right)$ & $\mathrm{A}_{1} \mathrm{~B}_{1}$ & $\mathrm{~A}_{2} \mathrm{~B}_{2}$ \\
\cline { 2 - 4 } Belajar (B) & Rendah $\left(\mathrm{B}_{2}\right)$ & $\mathrm{A}_{1} \mathrm{~B}_{2}$ & $\mathrm{~A}_{2} \mathrm{~B}_{2}$ \\
\hline
\end{tabular}

Keterangan:

$A_{l} B_{l}$ : kelompok siswa yang melaksanakan pembelajaran dengan Model TPS dan memiliki keaktifan belajar tinggi

$A_{1} B_{2}$ : kelompok siswa yang melaksanakan pembelajaran dengan model TPS dan memiliki keaktifan belajar rendah 
$A_{2} B_{1}$ : kelompok siswa yang melaksanakan pembelajaran dengan model konvensional dan memiliki keaktifan belajar tinggi

$A_{2} B_{2}$ :kelompok siswa yang melaksanakan pembelajaran dengan model konvensional dan memiliki keaktifan belajar rendah

Penelitian ini dilakukan di SMPN 2 Balocci Kabupaten Pangkep yang terletak di Kota Pangkep, Sulawesi Selatan. Populasi dalam penelitian ini adalah seluruh siswa kelas VII SMPN 2 Balocci tahun ajaran 2018-2019 yang terdiri dari 3 kelas dan jumlah siswa sebanyak 120 siswa. Teknik pengambilan sampel yang digunakan adalah Sampling Purposive. Sampel yang digunakan pada penelitian ini yaitu siswa kelas VII.1 dipilih sebagai kelas eksperimen dan kelas VII.2 dipilih sebagai kelas kontrol.

Pengumpulan data pada penelitian ini dilakukan teknik tes kemampuan komunikasi matematis dan angket keaktifan belajar. Pada penelitian ini dilakukan dua kali tes, yaitu pretest dan posttest. Pretest dilaksanakan untuk mengetahui kemampuan komunikasi matematis siswa sebelum diberi perlakuan, dan posttest dilakukan untuk mengetahui kemampuan komunikasi matematis siswa setelah diberi perlakuan. Selain tes, pada penelitian ini juga menggunakan angket keaktifan belajar siswa untuk mengelompokkan siswa ke dalam dua kelompok, yaitu kelompok siswa dengan keaktifan belajar tinggi dan keaktifan belajar rendah. Instrumen yang digunakan dalam penelitian berupa instrumen tes dan angket.

Pengolahan data hasil penelitian digunakan dua tekhnik statistik yaitu statistik deskriptif dan statistik inferensial. Analisis statistik deskriptif berfungsi untuk mengetahui gambaran secara umum kemampuan komunikasi matematis siswa. Analisis statistik inferensial digunakan untuk menguji hipotesis penelitian dengan menggunakan uji-t, namun sebelumnya dilakukan terlebih dahulu uji normalitas dan uji homogenitas sebagai uji prasyarat.

\section{HASIL DAN PEMBAHASAN}

Berikut ini adalah tabel hasil analisis deskriptif data kemampuan pemahaman konsep siswa di SMPN 2 Balocci Kabupaten Pangkep:

Tabel 3. Deskripsi Data Kemampuan komunikasi matematis Siswa Kelas Eksperimen

\begin{tabular}{llllll}
\hline \multirow{2}{*}{$\begin{array}{l}\text { Tingkat } \\
\text { Penguasaan }\end{array}$} & Kategori & Pretest & \multicolumn{3}{l}{ Posttest } \\
\cline { 3 - 6 } & & Jml. Siswa & $\mathbf{( \% )}$ & Jml. Siswa & (\%) \\
\hline $0-20$ & Sangat rendah & 0 & 0 & 0 & 0 \\
\hline $21-40$ & Rendah & 25 & 80,6452 & 0 & 0 \\
\hline $41-60$ & Sedang & 6 & 19,3549 & 0 & 0 \\
\hline $61-80$ & Tinggi & 0 & 0 & 17 & 54,8387 \\
\hline $81-100$ & Sangat tinggi & 0 & 0 & 14 & 45,1613 \\
\hline Jumlah & & 31 & 100 & 31 & 100 \\
\hline
\end{tabular}


Berdasarkan tabel 3, dapat diketahui bahwa kemampuan komunikasi matematis siswa pada pretest kelas eksperimen berkisar pada kategori rendah dengan persentase sebesar $80,6452 \%$ dan pada kategori sedang dengan persentase 19,3549\%. Sedangkan kemampuan komunikasi matematis siswa pada postest kelas eksperimen berkisar pada kategori tinggi dengan presentase $54,8387 \%$, dan pada kategori sangat tinggi dengan presentase $45,1613 \%$. Jadi terjadi kenaikan pada kategori sangat tinggi setelah diterapkan model TPS yaitu dari $0 \%$ menjadi $45,1613 \%$.

Tabel 4. Deskripsi Data Kemampuan komunikasi matematis Siswa Kelas Kontrol

\begin{tabular}{llllll}
\hline \multirow{2}{*}{$\begin{array}{l}\text { Tingkat } \\
\text { Penguasaan }\end{array}$} & Kategori & Pretest & \multicolumn{3}{l}{ Posttest } \\
\cline { 3 - 6 } & & Jml. Siswa & $\mathbf{( \% )}$ & Jml. Siswa & (\%) \\
\hline $0-20$ & Sangat rendah & 3 & 9,6774 & 0 & 0 \\
\hline $21-40$ & Rendah & 25 & 80,6452 & 0 & 0 \\
\hline $41-60$ & Sedang & 3 & 9,6774 & 0 & 0 \\
\hline $61-80$ & Tinggi & 0 & 0 & 26 & 83,8710 \\
\hline $81-100$ & Sangat tinggi & 0 & 0 & 5 & 16,1290 \\
\hline Jumlah & & 31 & 100 & 31 & 100 \\
\hline
\end{tabular}

Berdasarkan tabel 5, dapat diketahui bahwa kemampuan pemahaman konsep siswa pada pretest kelas kontrol berkisar pada kategori Sangat rendah dengan persentase sebesar 9,6774\%, pada kategori rendah dengan persentase sebesar $80,6452 \%$ dan pada kategori sedang dengan persentase 9,6774\%. Sedangkan kemampuan komunikasi matematis siswa pada postest kelas kontrol berkisar pada kategori tinggi dengan persentase $83,8710 \%$ dan pada kategori sangat tinggi dengan presentase $16,1290 \%$. Jadi terjadi kenaikan pada kategori sangat tinggi setelah diterapkan model pembelajaran langsung yaitu dari $0 \%$ menjadi 16,1290\%.

Berdasarkan data yang diperoleh dapat dilihat bahwa rata-rata nilai siswa mengalami kenaikan sebesar 45,1613 pada kelas eksperimen dan 16,1290 pada kelas kontrol. Hal tersebut dapat terjadi karena pada saat proses pembelajaran berlangsung, semua siswa memperoleh kesempatan untuk mengembangkan ide-ide yang ada di dalam pikirannya. Selain itu, siswa juga dituntut untuk saling berdiskusi, mengeluarkan gagasan atau pendapatnya, dan siswa juga mempresentasikan pemikirannya berdasarkan argumen-argumennya. Suasana kelas yang aktif dapat membangkitkan semangat , motivasi siswa dan keaktifan belajar untuk terus belajar dan berusaha untuk lebih kreatif dalam menyelesaikan permasalahan matematika yang diberikan. Berdasarkan uraian tersebut dapat diketahui bahwa terjadi peningkatan kemampuan komunikasi matematis siswa setelah diterapkannya model pembelajaran TPS. 
Tabel 5. Deskripsi Data Kategori Keaktifan Belajar Kelas Eksperimen

\begin{tabular}{cccc}
\hline \multirow{2}{*}{$\begin{array}{c}\text { Tingkat } \\
\text { Penguasaan }\end{array}$} & Kategori & \multicolumn{2}{c}{ Angket Keaktifan Kelas Eksperimen } \\
\cline { 3 - 4 } & & Frekuensi & Presentase \\
\hline $22-65$ & Rendah & 11 & 35,48 \\
\hline $66-110$ & Tinggi & 20 & 64,51 \\
\hline Jumlah & & 31 & 100 \\
\hline
\end{tabular}

Berdasarkan tabel di atas, dapat dilihat bahwa keaktifan beprestasi siswa kelas eksperimen yaitu 11 siswa (35,48 \%) berada pada kategori rendah dan 20 siswa $(64,51 \%)$ berada pada kategori tinggi. Jadi, dapat disimpulkan bahwa persentase terbesar keaktifan belajar siswa kelas eksperimen berada pada kategori tinggi.

Tabel 6 Deskripsi Data Kategori Keaktifan Belajar Kelas Kontrol

\begin{tabular}{cccc}
\hline Tingkat & \multirow{2}{*}{ Kategori } & \multicolumn{2}{c}{ Angket keaktifan belajar kelas eksprerimen } \\
\cline { 3 - 4 } Penguasaan & & Frekuensi & Persentase (\%) \\
\hline $22-65$ & Rendah & 12 & 38,70 \\
\hline $66-110$ & Tinggi & 19 & 61,30 \\
\hline Jumlah & & $\mathbf{3 1}$ & $\mathbf{1 0 0}$ \\
\hline
\end{tabular}

Berdasarkan tabel di atas, dapat dilihat bahwa keaktifan beprestasi siswa kelas eksperimen yaitu 12 siswa (38,70 \%) berada pada kategori rendah dan 19 siswa (61,30 $\%)$ berada pada kategori tinggi. Jadi, dapat disimpulkan bahwa persentase terbesar keaktifan belajar siswa kelas kontrol berada pada kategori tinggi

Hasil analisis statistik inferensial menggunakan uji t menunjukkan bahwa

1. Untuk perbedaan antara TPS dengan metode konvensional terhadap kemampuan komunikasi matematis siswa, Fhitung $=174,556>$ Ftabel $0,05(2 ; 70)=3,13$ dan nilai Sig. $<=0,000<0,05$, maka dapat disimpulkan bahwa terdapat perbedaan yang signifikan antara TPS dan metode konvensional terhadap kemampuan komunikasi matematis siswa kelas VII SMPN 2 Balocci, sehingga H0 ditolak.

2. Untuk pengaruh interaksi antara model TPS melalui keaktifan belajar terhadap Kemampuan komunikasi matematis siswa, Karena $F_{0}=23,962>$ F 0,05 $(2 ; 70)=3,13$, maka H0 ditolak dan nilai Sig. $<=0,000<0,05$, sehingga dapat disimpulkan bahwa terdapat pengaruh interaksi antara model pembelajaran ditinjau dari keaktifan belajar terhadap Kemampuan komunikasi matematis siswa kelas VII SMPN 2 Balocci.

3. Untuk perbedaan keaktifan belajar tinggi siswa yang menggunakan Think Pair Share dan tanpa penggunaan Think Pair Share, diperoleh pada equal variances assumed nilai signifikansi 0,431 dan nilai thitung 11,942. Pada taraf kepercayaan 95\% ( $\alpha=5 \%$, karena uji bersifat dua sisi, maka nilai $\alpha$ yang dirujuk adalah $\alpha / 2=5 \% / 2=0,025$ ) dan derajat bebas $(d k=n-2)=62-2=60$ tidak ada dalam tabel $t$, sehingga diambil $d k$ yang mendekati yakni 40), sehingga nilai ttabel $=t(0,025 ; 59)=2,021$. Hal itu berarti nilai Sig $>\alpha$ yaitu 0,431 >0,05 dan ttabel $\leq$ thitung yaitu 2,021 $\leq 11,942$. Kesimpulan yang diambil adalah $H 0$ ditolak atau Terdapat perbedaan keaktifan belajar tinggi siswa yang menggunakan Think Pair Share dan tanpa penggunaan Think Pair. Hal itu berarti peneliti dapat menyimpulkan bahwa keaktifan belajar tinggi matematis siswa berbeda secara signifikan. 
4. Untuk perbedaan keaktifan belajar rendah siswa yang menggunakan Think Pair Share dan tanpa penggunaan Think Pair Share, diperoleh pada equal variances assumed nilai signifikansi 0,009 dan nilai thitung 8,624. Pada taraf kepercayaan 95\% ( $\alpha=5 \%$, karena uji bersifat dua sisi, maka nilai $\alpha$ yang dirujuk adalah $\alpha / 2=5 \% / 2=0,025$ ) dan derajat bebas $(d k=n-2)=62-2=60$ tidak ada dalam tabel $t$, sehingga diambil $d k$ yang mendekati yakni 40 ), sehingga nilai ttabel $=t(0,025 ; 59)=2,021$. Hal itu berarti nilai $\operatorname{Sig}>\alpha$ yaitu 0,009 $>0,05$ dan ttabel $\leq$ thitung yaitu 2,021 $\leq 8,624$. Kesimpulan yang diambil adalah $\mathrm{HO}$ ditolak atau Terdapat perbedaan keaktifan belajar rendah siswa yang menggunakan Think Pair Share dan tanpa penggunaan Think Pair Share. Hal itu berarti peneliti dapat menyimpulkan bahwa keaktifan belajar rendah matematis siswa berbeda secara signifikan.

\section{SIMPULAN}

Perbandingan kemampuan komunikasi matematis siswa pada kelas yang menerapkan model pembelajaran TPS dengan kelas yang menerapkan model pembelajaran langsung diperoleh kenaikan rata-rata masing-masing untuk kelas ekeperimen adalah 45,1613\% dan untuk kelas kontrol 16,1290\%. Terdapat pengaruh interaksi antara model pembelajaran ditinjau dari keaktifan belajar terhadap Kemampuan komunikasi matematis siswa kelas VII SMPN 2 Balocci. Terdapat perbedaan keaktifan belajar tinggi antara penggunaan TPS dan tanpa penggunaan TPS terhadap kemampuan komunikasi matematis siswa. Terdapat perbedaan keaktifan belajar rendah antara penggunaan TPS dan tanpa penggunaan TPS terhadap kemampuan komunikasi matematis siswa.

\section{DAFTAR PUSTAKA}

Abdullah, Ridwan. (2014). Inovasi Pembelajaran. Jakarta: Bumi Aksara.

Azizah, Siti Maryam Noer. "Pengaruh Penerapan Model Pembelajaran Kooperatif Think Pair Share (TPS) terhadap Kemampuan Komunikasi Matematis Siswa". Skripsi. Jakarta : Fakultas Ilmu Tarbiyah dan Keguruan Universitas Islam Negeri Syarif Hidayatullah. 2011.

Huda, Miftahul. (2015). Model-Model Pengajaran dan Pembelajaran. Yogyakarta : Pustaka Pelajar.

Hutagalung, Inge. (2015). Teori-teori Komunikasi dalam Pengaruh Psikologi. Jakarta Barat: Indeks

Kurniasih, Imas. (2016). Ragam Pengembangan Model Pembelajaran untuk Peningkatan Profesionalisme Guru. Jakarta : Kata Pena

Lestari, Karunia Eka dan Mokhammad Ridwan Yudhanegara. (2006). Prosedur Penelitian Suatu Pendekatan Praktek . Jakarta: PT. Rineka Cipta

Lestari, Karunia Eka dan Mokhammad Ridwan. (2015) Penelitian Pendidikan Matematika. Jakarta: PT Refika Aditama

National Council of Teachers of Mathematics. (2000). Principles and Standart School for Mathematic. Reston, VA: NCTM

Rubiyanto, Nanik. (2010). Strategi Pembelajaran Holistik di Sekolah. Jakarta: Prestasi Pustaka 
Rusman. (2016). Model-Model Pembelajaran. Jakarta : PT Raja Grafindo

Suhana, Cucu. (2014). Konsep Strategi Pembelajaran. Bandung: Refika Aditama

Suprijono, Agus. (2014). Cooperative Learning Teori dan Aplikasi PAIKEM. Surabaya: Pustaka Pelajar

Surajiyo. (2009). Filsafat Ilmu dan Perkembangannya di Indonesia. Jakarta : Bumi Aksara.

Yamin. (2015). Moh.Teori Dan Metode Pembelajaran. Malang: Madani 